\title{
Impact of trematode parasitism on the fauna of a North Sea tidal flat
}

\author{
G. Lauckner \\ Biologische Anstalt Helgoland (Litoralstation); \\ D-2282 List/Sylt, Federal Republic of Germany
}

\begin{abstract}
The impact of larval trematodes on the fauna of a North Sea tidal flat is considered at the individual and at the population level, depicting the digenean parasites of the common periwinkle, Littorina littorea, and their life cycles, as an example. On the German North Sea coast, L. littorea is first intermediate host for 6 larval trematodes representing 6 digenean families Cryptocotyle lingua (Heterophyidae), Himasthla elongata (Echinostomatidae), Renicola roscovita (Renicolidae), Microphallus pygmaeus (Microphallidae), Podocotyle atomon (Opecoelidae) and Cercaria lebouri (Notocotylidae). All except $P$, atomon utilize shore birds as final hosts; adult $P$. atomon parasitize in the intestine of teleosts, mainly pleuronectid flatfish. Second intermediate hosts of $C$. lingua are various species of fish; the cercariae of $H$. elongata encyst in molluscs and polychaetes, those of $R$. roscovita in molluscs; M. pygmaeus has an abbreviated life cycle; $C$. lebouri encysts free on solid surfaces; and the fish trematode $P$. atomon utilizes benthic crustaceans, mainly amphipods, as second intermediate hosts. On the tidal flats of the Königshafen (Sylt), up to $77 \%$ of the periwinkles have been found to be infested by larval trematodes. Maximum infestations in individual samples were $23 \%$ for $C$. lingua, $47 \%$ for $H$. elongata and $44 \%$ for $R$. roscovita. The digeneans cause complete 'parasitic castration' of their carriers and hence exclude a considerable proportion of the snails from the breeding population. Infestation reduces the longevity of affected hosts, and size-related, trematode-induced differential mortality causes changes in the normal sizefrequency distribution of individual snail-age classes. Young flatfish Pleuronectes platessa from the Königshafen are $100 \%$ infested with metacercariae of $C$. lingua. Heavy infestation of the gills causes obstruction of blood vessels and respiratory impairment; metacercariae in the eyes and optic nerves cause visual and neurological disturbances. A single metacercaria is sufficient to kill a larval fish. Mytilus edulis and Cardium (Cerastoderma) edule are $100 \%$ infested with metacercariae of $H$. elongata. Heavy infestation impairs the byssus-thread production in mussels and affects the burrowing ability of cockles. Longevity and resistance to environmental - particularly thermal stress are reduced in bivalves infested with $H$. elongata and $R$. roscovita. There is evidence that, in the study area, population size and age composition of the molluscs discussed are (indirectly) controlled by trematode parasites employing sea birds as final hosts, rather than directly by the predatory activities of these birds.
\end{abstract}

\section{INTRODUCTION}

The trophic dynamics of ecosystems are usually considered mainly in terms of predator - prey relationships. Another no less important category of interrelationships, that of hosts and their parasites, has been neglected in most of the pertinent ecosystem analyses.

The purpose of this study is to present evidence of the impact of larval trematodes on several members of the animal community of a North Sea tidal flat, depicting the common periwinkle, Littorina littorea, and its digenean parasites as an example. 


\section{THE INVESTIGATION AREA}

The Königshafen (Fig. 1) is a shallow leeside bay situated at the northern tip of the Isle of Sylt $\left(55^{\circ} 3^{\prime} \mathrm{N} 8^{\circ} 25^{\prime} \mathrm{E}\right)$. At low tide, large areas of sand and mud flats, as well as mussel beds, are uncovered. During this time the flats are frequented by sea birds that

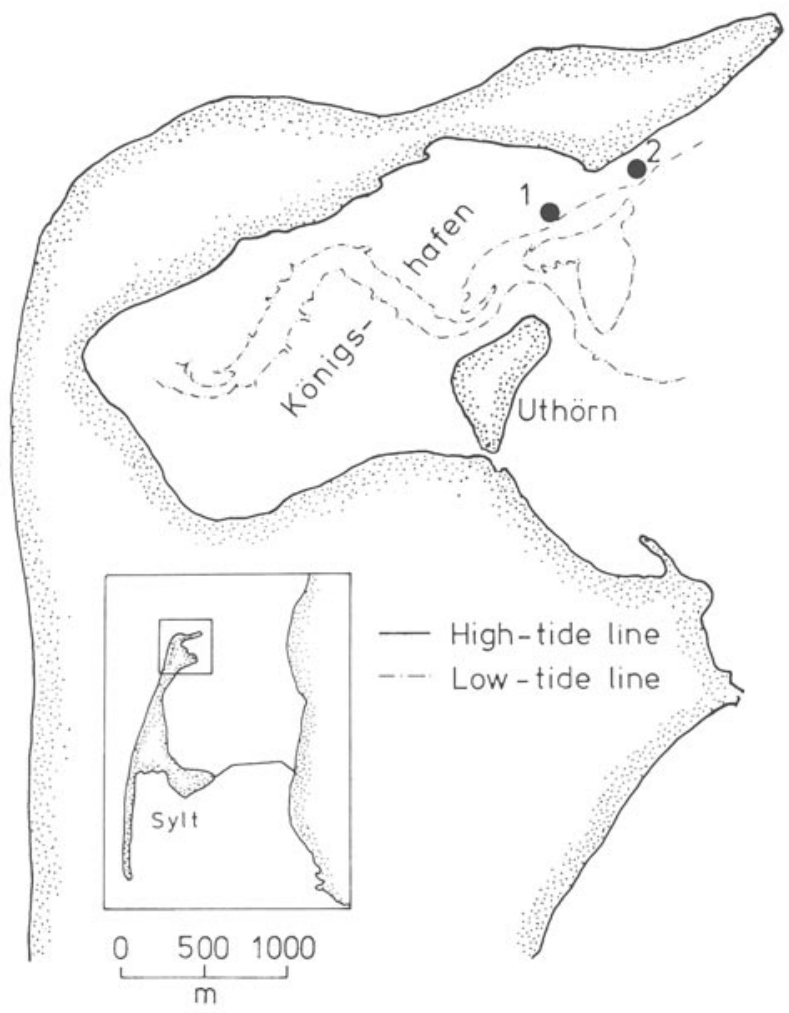

Fig. 1. The 'Königshafen' at List, North Sea, Isle of Sylt (Federal Republic of Germany), showing Stations 1 and 2

feed on the bottom invertebrates. The islet of Uthörn is a wildlife preserve providing roosting and breeding places for a species-rich avifauna. Major epifaunal elements of the flats are - in terms of biomass - the blue mussel, Mytilus edulis, the common cockle, Cardium (Cerastoderma) edule, and the periwinkle, Littorina littorea.

The ecology of the Königshafen has been studied by Wohlenberg (1937). However, except for a few brief notes (Lauckner, in Biologische Anstalt Helgoland, Jahresbericht 1974,1978 ) and two more general publications referring only in part to material from that area (Werding, 1969; Lauckner 1971), there have been no studies on the parasitofauna of the Königshafen.

\section{MATERIALS AND METHODS}

Periwinkles and molluscan second intermediate hosts - mainly Mytilus edulis and Cardium (Cerastoderma) edule - were hand-collected at low tide. Juvenile flatfish were 
dip-netted during ebb tide. The collected invertebrates were transferred to the laboratory and maintained in aerated, daily changed sea water until examination. Periwinkles were allowed to defecate for at least $24 \mathrm{~h}$ in order to facilitate recognition of recently established, immature digenean infestations. By means of a caliper rule, the spindle height of Littorina littorea was measured to the nearest $1 / 10 \mathrm{~mm}$, and individuals were subsequently grouped in $1.0 \mathrm{~mm}$ size intervals. The resulting multimodal size-frequency distributions (which represent overlapping year classes) were dissected into their normal components by means of a computer program based on the method outlined by Akamine (1982).

Bivalves used in the infestation and survival experiments were collected from tidal flats outside the Königshafen, i.e. from sites with low overall trematode prevalence. All individuals were acclimated to laboratory conditions $\left(20^{\circ} \mathrm{C}, 30 \% \mathrm{~S}, 16: 8 \mathrm{~h}\right.$ day/night rhythm) for at least 5 days prior to the experiments.

Cryptocotyle lingua infestation in juvenile Pleuronectes platessa has been studied more thoroughly in the author's laboratory by Kelle-Emden (1979). The methods described in detail in that paper have been adopted in the present investigation.

\section{RESULTS}

Six species of larval trematodes representing 6 digenean families have been reported from North Sea periwinkles (Werding, 1969), and all of these occur in Littorina littorea from the Königshafen. Their life cycles are summarized in Figure 2. All except Podocotyle atomon utilize sea birds as definite hosts. The first three species are of

Life cycles of Littorina parasites

\begin{tabular}{|c|c|}
\hline $\begin{array}{l}\text { Cryptocotyle lingua (Heterophyidae): } \\
\text { L. littorea } \longrightarrow \text { Fishes }\end{array}$ & Sea birds \\
\hline $\begin{array}{l}\text { Himasthla elongata (Echinostomatidae } \\
\text { L. Iittorea } \longrightarrow \text { Molluscs } \\
\text { Annelids }\end{array}$ & Sea birds \\
\hline $\begin{array}{l}\text { Renicola roscovita (Renicolidae): } \\
\text { L. littorea } \longrightarrow \text { Molluscs }\end{array}$ & Sea birds \\
\hline $\begin{array}{l}\text { Microphallus pygmaeus (Microphallid } \\
\text { L. littorea } \longrightarrow \text { (L. littorea) }\end{array}$ & Sea birds \\
\hline $\begin{array}{l}\text { Cercaria lebouri (Notocotylidae): } \\
\text { L. littorea }\end{array}$ & $\rightarrow$ Sea birds \\
\hline
\end{tabular}

Fig. 2. Life cycles of digenetic trematodes utilizing Littorina littorea as first intermediate host

considerable concern because they employ commercially important vertebrates or invertebrates as second intermediate hosts. The other three, which occur in low prevalence, will not be considered in detail.

In the Königshafen, trematode infestation of periwinkles may reach enormous levels. At most stations sampled, overall infestation percentages in adult $L$. littorea were 


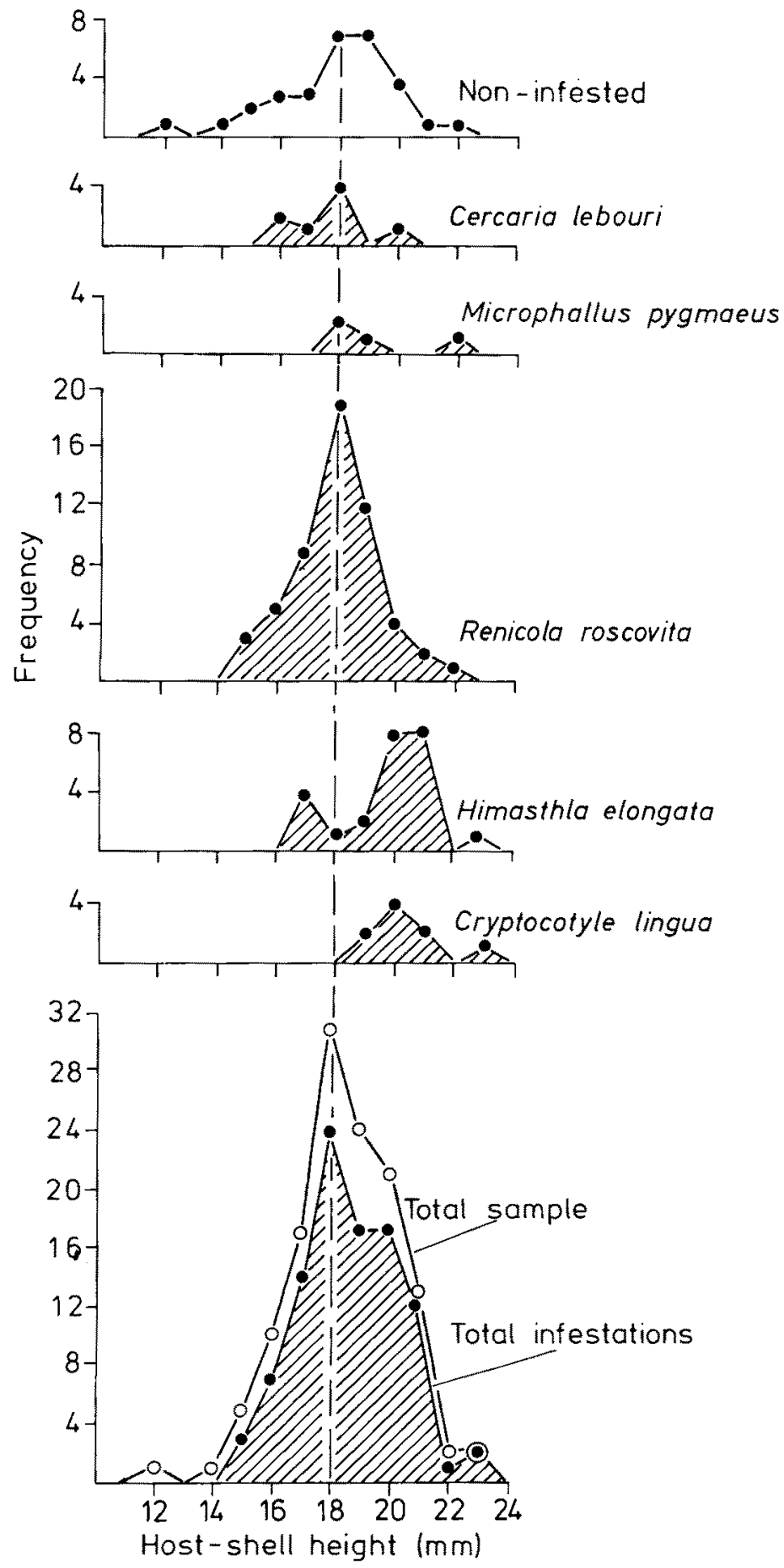

Fig. 3. Littorina littorea. Length-frequency distribution and trematode infestation of sample taken at Station 1 (see Fig. 1) 
well above $50 \%$, with a maximum of $77 \%$ observed in a snail sample (Fig. 3) taken from a mussel bank near the entrance of the bay, a favourite roosting and feeding place of gulls Larus spp., oystercatchers Haematopus ostralegus and Eider ducks Somateria mollissima. Maximum infestation incidences recorded for individual parasite species in Littorina samples from the area were $23 \%$ for Cryptocotyle lingua, $44 \%$ for Renicola roscovita and $47 \%$ for Himasthla elongata. A more detailed analysis of the dynamics of trematode infestation in littorines from the Königshafen will be given elsewhere (Lauckner, in preparation).

Most of the infestations encountered were mature and the resultant host pathology severe. Gonad atrophy ('parasitic castration') was apparent in almost all infested hosts, as was penis reduction in males. The larval digeneans differ with respect to their pathogenicity in the first intermediate host (for review of literature see Lauckner, 1980). Since each species exhibits a distinct preference for certain host-size classes (Fig. 3), the resultant parasite-produced differential mortality of infested hosts causes significant distortions of the original size-frequency distribution of the L. littorea population. In extreme cases (Fig. 4), grotesque multimodal distribution patterns arise, which cannot be resolved into individual normal components representing successive year classes. Simi-

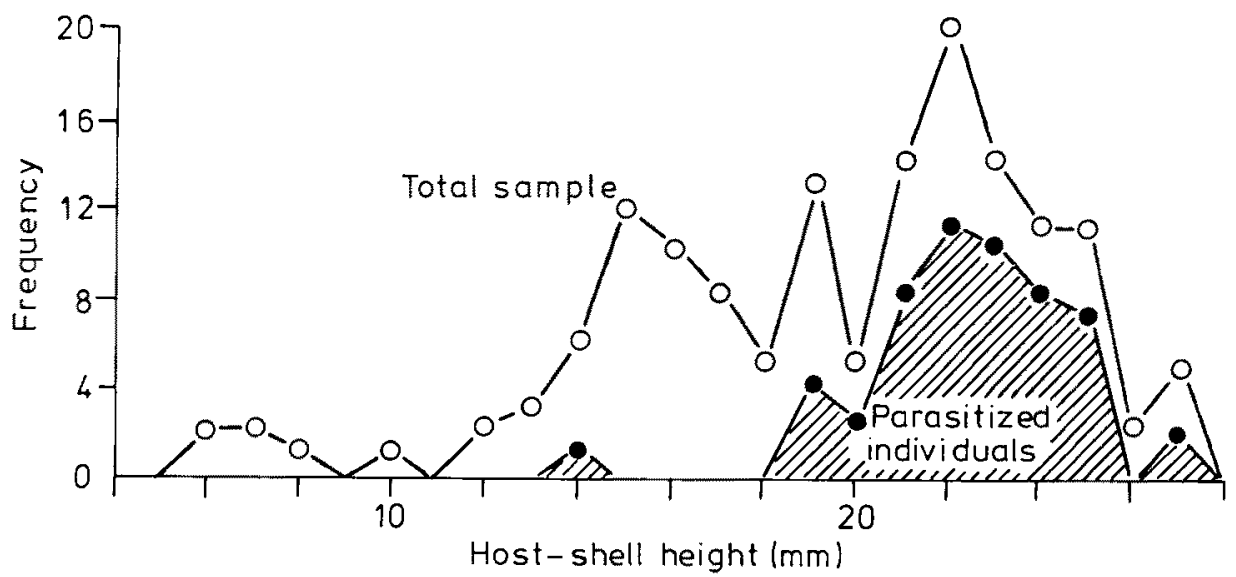

Fig. 4. Littorina littorea. Grotesque distortion of length-frequency distribution caused by parasiteproduced differential mortality. Sample taken at Station 2 (see Fig. 1)

larly, no reproducible von Bertalanffy growth parameters can be computed for such affected periwinkle populations.

As a consequence of these erratic deviations, no mortality estimates can be made from analyses of the changes of the periwinkles' size-frequency distribution. However, simultaneous collection of living snails and dead shells form the same locality provides a rough idea of the amount of differential mortality (Fig. 5a). The sample contains $n_{1}=147$ living $L$. littorea and $\mathrm{n}_{2}=167$ dead shells. Combination of both groups yields a sizefrequency curve (Fig. 5b), which can be resolved into 3 normal components. Hence, the combined curves reflect, with a high degree of probability, the condition that had existed prior to the onset of mortality. From the number of (dead plus living) periwinkles in the whole sample minus the number of dead shells, the mortality - which is believed to be 


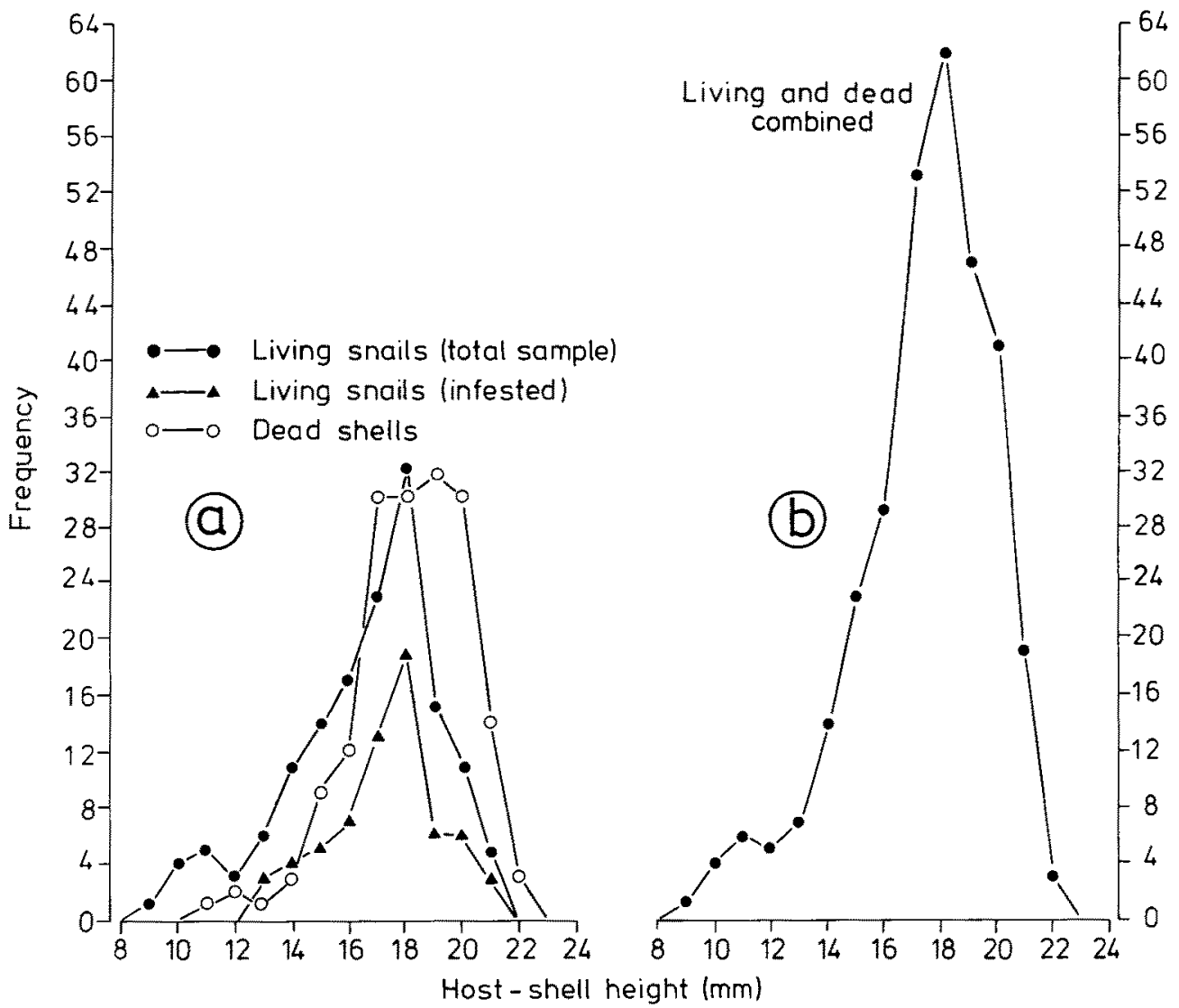

Fig. 5. Littorina littorea. (a) Size-frequency distributions of living individuals and dead shells. (b) Both distributions combined. Sample taken from Ho Bugt, Esbjerg, Denmark

primarily related to trematode parasitism - can be estimated. In the present case (a sample taken from Ho Bugt, Esbjerg, Denmark) it is in excess of $50 \%$.

Concomitantly with the high prevalence of trematodes in L. littorea, infestations of second intermediate hosts with metacercariae may reach epizootic levels. Young flatfish collected in the tide pools and channels of the Königshafen were found to be $100 \%$ infested with $C$. lingua in varying degrees of intensity. Up to 109 metacercariae of this digenean have been counted in plaice approximately $4 \mathrm{~cm}$ in length (Kelle-Emden, 1979). The site of the parasite within the fish body, rather than the absolute number of cysts per host, appears to determine the fate of the suscept, encystment in the gill tissue causing obstruction of blood vessels and respiratory impairment, and penetration of the eyes, optic nerves or other parts of the brain leading to visual or neural disturbances. A single metacercaria of $C$. lingua is sufficient to kill a larval fish (Fig. 6).

$H$. elongata typically occurs in highest infestation rates in $L$. littorea from sheltered, shallow bays. It may be recalled that, in some parts of the Königshafen, up to $47 \%$ of the periwinkle population are infested with the rediae of this species, which utilizes bivalves and, to a lesser extent, annelids and gastropods as second intermediate hosts. In 


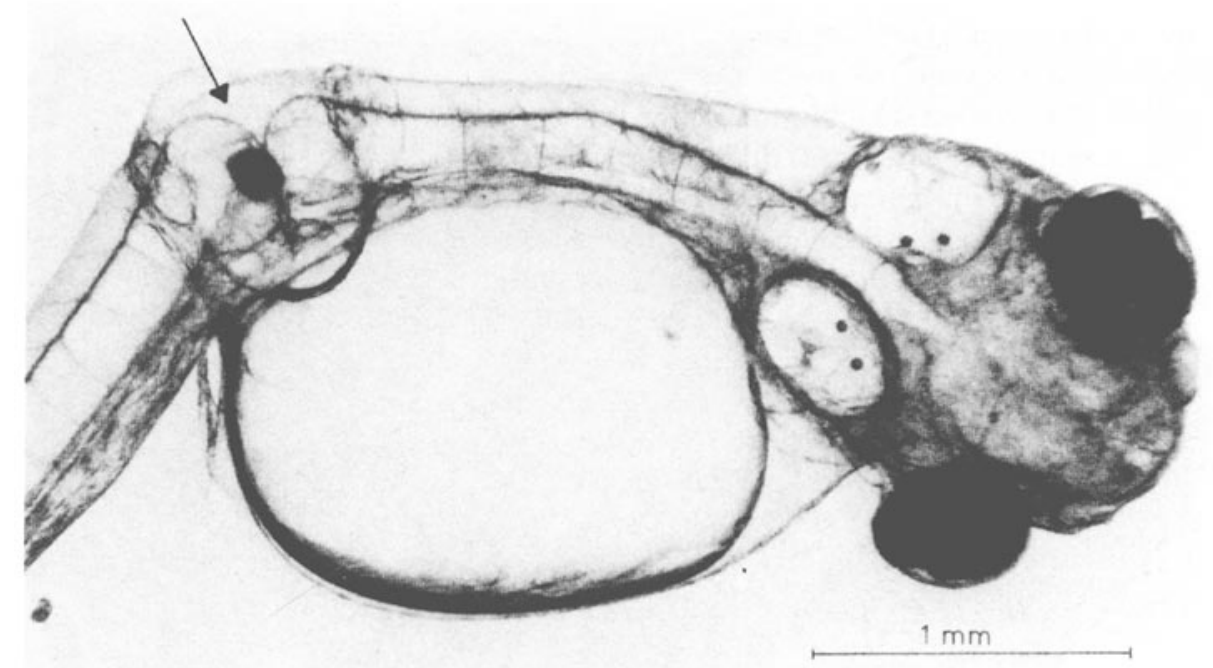

Fig. 6. Herring (Clupea harengus) larva killed by encysting Cryptocotyle lingua metacercaria (arrow)

molluscs, the cercariae almost invariably encyst in the foot musculature. In the Königshafen, Mytilus edulis and Cardium edule, the main secondary host species, are $100 \%$ infested with $H$. elongata metacercariae. Frequently, the foot of these bivalves is so riddled with cysts that its vital functions are severely impaired (Fig. 7).

Experiments were conducted to determine the effect of $H$. elongata on byssus-thread production in young $M$. edulis. Uninfested mussels produced $31 \pm 17$ threads within $22.5 \mathrm{~h}$ and $62 \pm 26$ threads within $77.5 \mathrm{~h}$. Within the same time intervals, individuals infested with $116 \pm 66$ cysts produced only 22 and 40 threads, respectively. The differences are statistically highly significant (Lauckner, 1983).

Cardium (Cerastoderma) edule is similarly affected by $H$. elongata. The cockle normally lives entirely burrowed in the sediment, only the siphon openings being visible at the substrate surface. In the Königshafen, numerous cockles can be seen which are partially or totally uncovered. Many have been spun together in bundles by the byssus threads of mussels. Inspection of such cockles almost invariably reveals the presence of large numbers of metacercarial cysts in the foot musculature.

When placed on sandy substratum, juvenile cockles experimentally infested with $H$. elongata metacercariae remained at the sediment surface for considerable time, while uninfested controls burrowed rapidly. The median time ( = mean of log time) after which $50 \%$ of the healthy cockles were entirely burrowed was $12.5 \mathrm{~min}$, as opposed to about $290 \mathrm{~min}$ required by the infested specimens. In order to determine whether the effect exerted by the metacercariae is mechanical or physiological, or both, another group of cockles was experimentally infested with cercariae of Renicola roscovita, which invade the palps rather than the foot. There was no deviation in the median burrowing time of this group from that of the uninfested control. Therefore, the effect of $H$. elongata metacercariae on the burrowing ability of cockles was interpreted as being purely mechanical. 

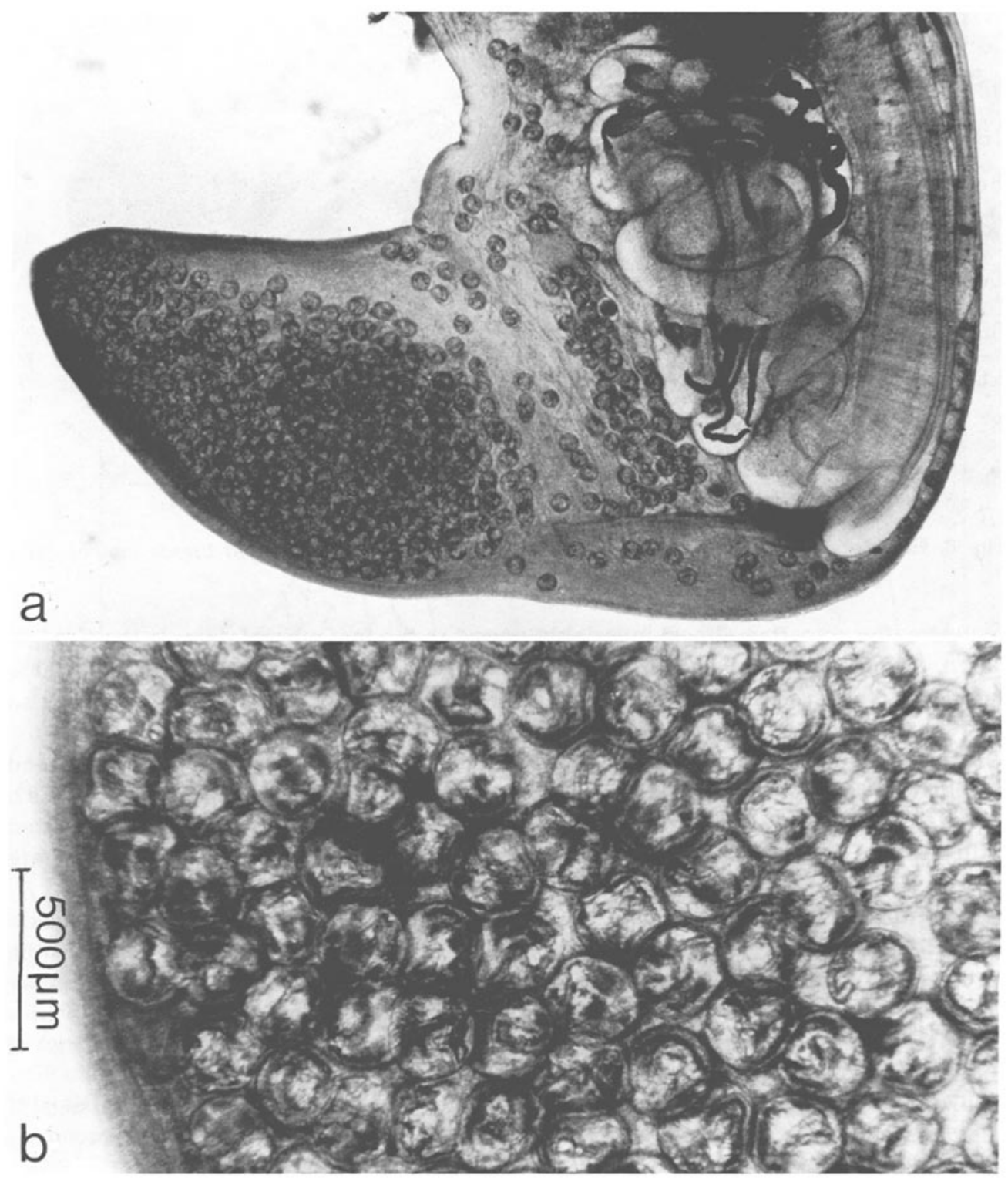

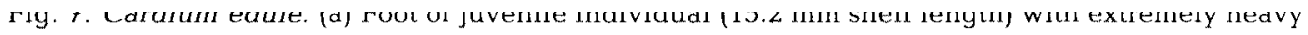
natural Himasthla elongata infestation showing distribution of 195 cysts; (b) enlarged portion of (a). Metacercariae, so densely packed that cysts deform each other, have almost entirely replaced hostmuscular tissue

In the burrowing experiment described, the cockles had been challenged with an uncounted number of $H$. elongata cercariae. Upon subsequent dissection, the number of metacercarial cysts per cockle was found to be in the range of some 30 to 55 . This was believed to be a fairly high number, which may have overcharged these small hosts. 
However, when examining naturally infested 0-group cockles, it was found that 250 $H$. elongata cysts per host were not uncommon. Figure $7 \mathrm{a}$, for example, shows the distribution of 195 metacercariae in the foot of a naturally infested juvenile cockle 15.2 $\mathrm{mm}$ in shell length. A cut-out of the same micrograph (Fig. 7b) shows that, in the most heavily invaded portion of the cockle's foot, the metacercariae are so densely packed that they deform each other and have almost entirely replaced the host's muscular tissue. It is hard to understand how such animals can stay alive - and in fact they do not survive very long.

The second important larval digenean utilizing mussels and cockles as secondary host is Renicola roscovita. Its sporocysts and cercariae occur in up to $44 \%$ of the $L$. littorea from the Königshafen, and mussels and cockles from that area are $100 \%$ infested with the metacercariae. In adult hosts, the latter inhabit mainly the palps, which may become as densely paved as the foot by $H$. elongata. In very small cockles (Table 1 , 'autumn spat'), $R$. roscovita metacercariae encyst mainly in the mantle margin and the visceral mass, which may be due to the fact that the tiny palps of these small hosts do not provide sufficient space to accomodate larger numbers of larval worms.

Table 1. Cardium edule. Microhabitat selection (percentage distribution) of 3 larval trematodes in various body parts of juvenile cockles

\begin{tabular}{|c|c|c|c|c|c|c|c|c|c|}
\hline $\begin{array}{l}\text { Trematode } \\
\text { species }\end{array}$ & Foot & $\begin{array}{l}\text { Mic } \\
\text { Palps }\end{array}$ & $\begin{array}{l}\text { rohabit } \\
\text { Gills }\end{array}$ & $\begin{array}{l}\text { Mat } \\
\text { Marntle } \\
\text { margin }\end{array}$ & $\begin{array}{l}\text { Vis- } \\
\text { ceral } \\
\text { mass }\end{array}$ & $\begin{array}{c}\text { Total } \\
\text { number } \\
\text { of meta- } \\
\text { cercariae }\end{array}$ & $\begin{array}{c}\text { Total } \\
\text { number } \\
\text { of hosts }\end{array}$ & $\begin{array}{c}\text { Number } \\
\text { (percentage) } \\
\text { of hosts } \\
\text { infested }\end{array}$ & $\begin{array}{c}\text { Mean } \\
\text { number of } \\
\text { metacerca- } \\
\text { riae infested } \\
\text { host }^{-1}\end{array}$ \\
\hline \multicolumn{10}{|l|}{ Himasthla elongata } \\
\hline in surnmer spat & 96.7 & 0 & 0 & 3.3 & 0 & 4,527 & 23 & $23(100 \%)$ & 196.8 \\
\hline in autumn spat & 97.0 & 0 & 0 & 3.0 & 0 & 33 & 24 & $9(37.5 \%)$ & 3.7 \\
\hline \multicolumn{10}{|c|}{ Himasthla interrupta } \\
\hline in summer spat & 0.5 & 0 & 0 & 99.5 & 0 & 186 & 23 & $22(95.7 \%)$ & 8.5 \\
\hline in autumn spat & 14.1 & 5.1 & 1.0 & 75.8 & 4.0 & 99 & 24 & $17(70.8 \%)$ & 5.8 \\
\hline \multicolumn{10}{|l|}{$\begin{array}{l}\text { Renicola roscovita } \\
\text { Percentage of cysts }\end{array}$} \\
\hline in summer spat & 0.6 & 71.7 & 2.1 & 10.5 & 15.1 & 3,879 & 23 & $23(100 \%)$ & 168.7 \\
\hline in autumn spat & 1.1 & 18.2 & 3.9 & 41.4 & 35.4 & 181 & 24 & $22(91.7 \%)$ & 8.2 \\
\hline
\end{tabular}

Both Himasthla and Renicola metacercariae adversely affect the heat tolerance of their bivalve hosts. As shown experimentally, the metacercariae of Renicola, which grow within the secondary host, have a physiologically more detrimental effect on the cockle than the non-growing Himasthla cysts (Lauckner, 1983).

The impact of larval trematodes on natural bivalve populations is difficult to determine by direct field observation. However, the destructive action of these parasites can be deduced from indirect evidence (Table 2): 
Table 2. Cardium edule. Intensity of trematode infestation in 0-group individuals

\begin{tabular}{|c|c|c|}
\hline & Summer spat & Autumn spat \\
\hline Number of hosts inspected & 23 & 24 \\
\hline Host-shell length ( $\mathrm{mm}_{;}$mean \pm standard deviation) & $15.55 \pm 2.05$ & $6.86 \pm 2.42$ \\
\hline Total number of cysts recovered & 8,592 & 316 \\
\hline Number of cyst hosts ${ }^{-1}$ (mean \pm standard deviation) & $373.6 \pm 100.0$ & $13.2 \pm 9.9$ \\
\hline \multicolumn{3}{|l|}{ Percentage of parasites involved } \\
\hline Himasthla elongata & 52.7 & 10.4 \\
\hline Himasthla interrupta & 2.2 & 31.3 \\
\hline Renicola roscovita & 45.1 & 57.3 \\
\hline Himasthla continua and Psilostomum brevicolle & 0 & 1.0 \\
\hline
\end{tabular}

0-group C. edule from the Königshafen, $15.55 \mathrm{~mm}$ in mean shell length, were found to harbour an average of 373.6 metacercarial cysts when examined at the beginning of the winter, i.e. at a time when cercarial emission by the first intermediate hosts has ceased. These individuals have been termed 'summer spat' because they were members of the major spatfall occurring in June to July. In some years there is a second period of minor spatfall or diffuse spawning occurring later in the year. These animals have accordingly been termed 'autumn spat'. They measured $6.86 \mathrm{~mm}$ in mean shell length and harboured, on the average, only 13.2 cysts when examined by the end of the first growth period. Infestations with $H$. elongata (which is the - mechanically - more deleterious parasite) make up $52.7 \%$ of the total infestations in the summer spat but only $10.4 \%$ in the autumn spat. $H$. interrupta, $H$. continua and Psilostomum brevicolle have their redial and cercarial stages in the gastropod Hydrobia ulvae (Loos-Frank, 1967, 1968). $H$. interrupta metacercariae occur in significant numbers only in autumn spat of $C$. edule. None of the juvenile Königshafen cockles, inspected for encysted trematodes in the following spring, had metacercarial numbers falling into the range of the summerspat counts obtained during the preceding autumn (Table 2).

\section{DISCUSSION}

The pathology of larval trematodes in Littorina littorea has been studied in detail at the individual level (Rees, 1936; Robson \& Williams, 1971a, b; Watts, 1971; and others). However, studies on the effects of digeneans on Littorinidae at the population level are scarce (for literature review see Lauckner, 1980).

Since the presence of rediae or sporocysts in L. littorea causes 'parasitic castration', a considerable proportion of periwinkles is, therefore, removed from the breeding population. It is obvious that infestation incidences in excess of $50 \%$, as prevailing in the Königshafen, must have a profound effect on the population dynamics and recruitment of the host species. The observed scarcity of Littorina veligers in plankton samples from the investigation area (P. Martens, pers. comm.) may be a direct result of the trematodecaused reduction of the reproductive potential of the periwinkle.

It has been suggested that infestation of $L$. Littorea with Cryptocotyle lingua, Himasthla elongata and Renicola roscovita may account for increased host mortality in 
the laboratory (Robson \& Williams, 1970), but field data are lacking. Long-term observations conducted at Sylt and in the Danish part of the Baltic Sea (Lauckner, in prep.) provide strong evidence for the assumption that the population dynamics of $L$. littorea in these waters are profoundly affected by larval digeneans.

In the second intermediate hosts, the pathology caused by the Littorina parasites is no less severe. The effects of $C$. lingua on fishes have been studied on several occasions. Sindermann \& Rosenfield (1954) have shown that 0 -group herring could be killed within 15 days, and individuals of Age Group I within 30 days, by massive continuous exposure to cercariae of $C$. lingua. Mackenzie (1968) identified massive infestation of young plaice with metacercariae of that species as the possible cause of mortality. According to Kelle-Emden (1979), young flatfish less than $4 \mathrm{~cm}$ in length are particularly affected by C. lingua. A single C. lingua cercaria is sufficient to kill a larval herring (Fig. 6). In the North and Baltic Seas, $C$. lingua is a very successful parasite capable of maintaining high spatial and temporal population stability in its intermediate and final hosts (Lauckner, 1984; Lauckner, in prep.). Therefore, its impact on the fish fauna of shallow inshore waters is obvious. The observation of $100 \% \mathrm{C}$. lingua infestation in juvenile flatfish from the Königshafen is alarming in view of the fact that the shallow parts of the Wadden Sea are important nursery grounds for plaice, dab and flounder.

Metacercariae encysting in marine bivalves are usually regarded as harmless (for literature and discussion of controversial opinions consult Lauckner, 1983). In contrast, detrimental effects of larval trematodes on the general performance of mussels and cockles have clearly been demonstrated by Lauckner (1983). Attachment to the substrate by means of byssus threads is of vital importance for Mytilus edulis and for the formation of intertidal banks (Maas Geesteranus, 1942). The - commercially unexploited - mussel banks of the Königshafen are at present grossly depleted, which may be due, in part, to the ice winters of the preceding years, and to bird predation. But the evidence presented in this study suggests that $H$. elongata infestations are an important contributing factor reducing the success of the mussel in establishing banks in shallow sheltered waters.

Byssus-thread production by $M$. edulis has been studied repeatedly (Glaus, 1968; Reish \& Ayers, 1968; Mahéo, 1970; Van Winkle, 1970; Martella, 1974; Martin et al., 1975; Allen et al., 1976; Carr \& Reish, 1978; Price, 1980). Curiously, none of these authors has taken into consideration the possible effects of larval trematodes on the byssal activity of their test individuals.

The deleterious effects of $H$. elongata on Cardium edule may be even more severe. Cockles rendered incapable of burrowing due to trematode infestation of the foot fall an easy prey to birds and scavengers. Individuals lying at the sediment surface are frequently cemented, by means of the byssus threads of $M$. edulis, to shell fragments, pebbles, etc., in order to provide a solid substratum for the mussel's attachment. Such 'captured' cockles rapidly die from desiccation during ebb tide.

It may be added in parentheses that behavioural changes similar to those reported for the Königshafen cockles - i.e. lying at the sediment surface instead of burrowing have been observed in individuals of Cardium lamarcki from shallow bays on the Danish Kattegat coast (i.e. near the entrance of the Baltic Sea). Inspection of these animals revealed high intensities of infestation with $H$. elongata metacercariae, and up to $34 \%$ of the $L$. littorea from the same area harboured the rediae of that species.

Experiments determining the possible effects of Renicola roscovita metacercariae on 
adult bivalves have not yet been conducted, but it appears likely that, in heavily infested hosts, the proper function of the palps as a particle transporting and sorting device may be impaired. At least juvenile cockles are severely debilitated by $R$. roscovita metacercariae, probably by those encysted in the gills and the visceral mass (Table 1).

The experiments and observations reported above mainly reflect the effects of larval digeneans on the second intermediate hosts at the in $\mathrm{d}$ ivi $\mathrm{du}$ a l level. What are now the effects of metacercarial attack on mussels, cockles and other susceptible hosts at the p opulation level?

The bivalve species inhabiting the tidal flats have their breeding season in late spring, the resulting major spatfalls occurring from late May to early August (Fig. 8).

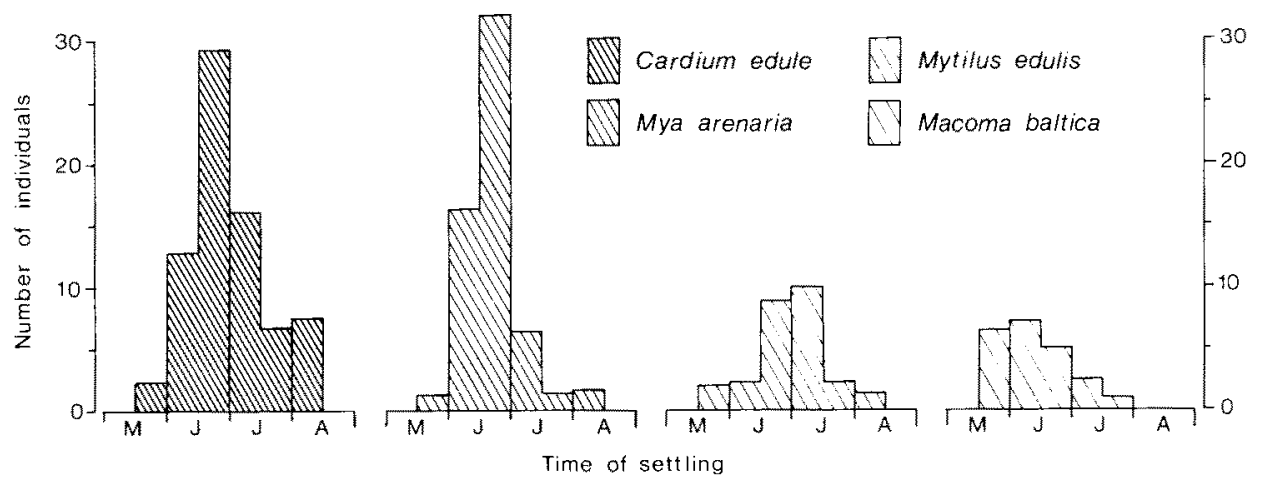

Fig. 8. Time of settling and average number of spat of several bivalve species on $20 \mathrm{dm}^{2}$ sediment area of a tidal flat. (Based on Baggerman, 1953)

This time interval coincides precisely with the period of major cercarial production in the primary host (Fig. 9). Hence, the young spat are overwhelmed with large numbers of cercariae immediately after settling. Single or a few metacercariae are sufficient to kill recently settled bivalve spat, although their ability to tolerate larger numbers of larval trematodes increases rapidly with size.

Since growth of the young bivalves is fast in the first summer, they do survive the initial period of major cercarial attack, provided that the number of encysting metacercariae is not too high. In the second year, maximum growth occurs prior to the onset of cercarial invasion and increases the capacity of the hosts to support additional numbers of metacercariae (Fig. 9). After the second summer, however, growth of the cockles slows down and can no longer keep up with the recurrent bombardment by larval trematodes. In areas of moderate-to-high Himasthla and Renicola prevalence, the more heavily infested cockles usually die during or after their third summer. This is the so-called 'summer mortality', usually believed to be associated with post-spawning emaciation. However, mortalities of this kind have nothing to do with the breeding cycle of Cardium and are not normally observable in areas devoid of larval trematodes or other stress parasites.

As has been stated, juvenile Cardium edule from the Königshafen usually yield considerably fewer metacercarial cysts by the end of their first winter than individuals 


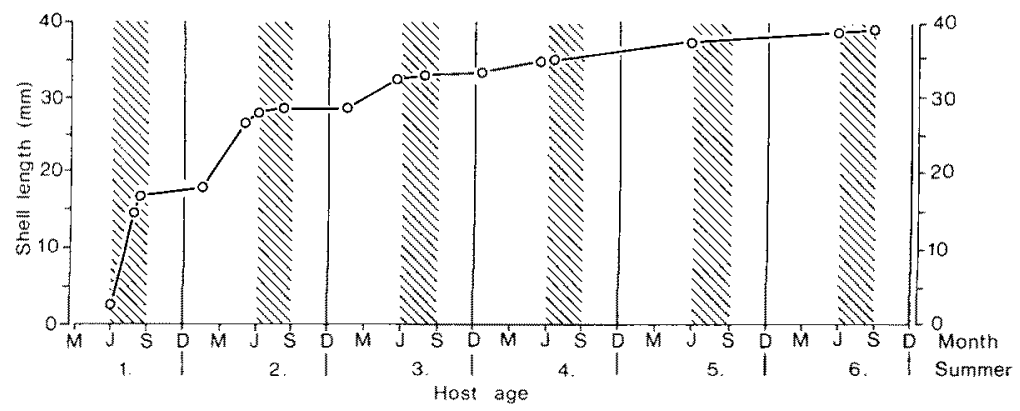

Fig. 9. Cardium edule. Relation between age, growth increment and major periods of cercarial attack (= crosshatched areas). (Based on Kristensen, 1957)

examined in the preceding autumn (Table 2). There is no indication that cockles or mussels are capable of sloughing off encysted $H$. elongata metacercariae. Resorption of dead cysts may occur on rare occasions, and presumably only in over-aged worms or in metacercariae killed by freezing. In fact, partial resorption has only been seen in metacercariae of Renicola roscovita encysted in the palps. From the drastic and rather sudden decline of metacercarial counts in juvenile cockles it may, therefore, reasonably be concluded that none of the highly infested summer-spat individuals had survived their first winter. A concomitant decline of metacercarial counts in the autumn-spat individuals indicates that this host cohort has undergone a similar parasite-caused mortality.

In the infestation experiments conducted it became apparent that the number of metacercariae required to kill a juvenile host may be quite variable. This circumstance reflects the microhabitat segregation displayed by the different species of metacercariae (Table 1). A few cysts in the visceral mass or in nervous tissues are beyond doubt more deleterious than a much larger number in the palps or the mantle margin. $H$. elongata invades almost exclusively the foot; $H$. interrupta cysts are largely confined to the mantle margin, but in very small cockles they also occur in the foot. Renicola prefers the palps as encystment site in larger hosts but the mantle margin in smaller hosts. The fairly high percentage of Renicola cysts in the visceral mass certainly accounts for the pathogenicity of even low absolute numbers of metacercariae in these small hosts.

In conclusion, it has been demonstrated that larval trematodes do not only affect cockles and mussels at the individual level but that - under ecological conditions prevailing in shallow bays such as the Königshafen - they even exert large-scale population control over their molluscan intermediate hosts. At least they do account for the larger part of what the ecologist terms 'natural mortality'.

It must be emphasized that Himasthla and Renicola are not the sole trematodes parasitizing North Sea bivalves. At least 9 larval digeneans occur in Cardium edule and 6 in Mytilus edulis from the Königshafen (Lauckner, 1977). Several are lethal disease agents. As the adults of all of these occur in sea birds, it becomes progressively evident, which link of the littoral ecosystem is responsible for what may be termed an 'ecological disaster'. However, any attempt to reduce sea bird abundance - at present the only conceivable measure that could be effective in restoring a balanced ecosystem 
in the Königshafen - would immediately call up the bird protectionists who are either ignorant or totally unaware of what their 'pets' are doing to the marine littoral fauna.

Acknowledgements. I am grateful to M. Söhl for technical assistance and to J. Marschall for preparing the drawings. H. Lauckner assisted with the collection of the material and typed the manuscript.

\section{LITERATURE CITED}

Akamine, T., 1982. A BASIC program to analyse the polymodal frequency distribution into normal distributions. (Japan., Engl. summary). - Bull. Jap. Sea reg. Fish. Res. Lab. 33, 163-166.

Allen, J. A., Cook, M., Jackson, D. J., Preston, S. \& Worth, E. M., 1976. Observations on the rate of production and mechanical properties of the byssus threads of Mytilus edulis L. - J. moll. Stud. 42, 279-289.

Baggerman, B, 1953. Spatfall and transport of Cardium edule L. - Archs néerl. Zool, 10, 315-342.

Carr, R. S. \& Reish, D. J., 1978. Studies on the Mytilus edulis community in Alamitos Bay, California: VII. The influence of water-soluble petroleum hydrocarbons on byssal thread formation. Veliger 21, 283-287.

Glaus, K. J., 1968. Factors influencing the production of byssus threads in Mytilus edulis. - Biol. Bull. mar. biol. Lab., Woods Hole 135, 420.

Kelle-Emden, A., 1979. Untersuchungen zur Okologie des digenen Trematoden Cryptocotyle lingua und seine Auswirkungen auf junge Plattfische. Dipl.-Arb., Univ. Kiel, 71 pp.

Kristensen, I., 1957. Differences in density and growth in a cockle population in the Dutch Wadden Sea. - Archs néerl. Zool. 12, 351-453.

Lauckner, G., 1971. Zur Trematodenfauna der Herzmuscheln Cardium edule und Cardium lamarcki. - Helgoländer wiss. Meeresunters. 22, 377-400.

Lauckner, G., 1980. Diseases of Mollusca: Gastropoda. In: Diseases of marine animals. Ed. by O. Kinne. Wiley, Chichester, 1, 311-424.

Lauckner, G., 1983. Diseases of Mollusca: Bivalvia. In: Diseases of marine animals. Ed. by O. Kinne Biologische Anstalt Helgoland, Hamburg, 2, 477-961.

Lauckner, G., 1984. Brackish-water submergence of the common periwinkle, Littorina littorea, and its digenean parasites in the Baltic Sea and in the Kattegat. - Helgoländer Meeresunters. 37, $177-184$.

Loos-Frank, B., 1967. Experimentelle Untersuchungen über Bau, Entwicklung und Systematik der Himasthlinae (Trematoda, Echinostomatidae) des Nordseeraumes. - Z. ParasitKde 28, 299-351.

Loos-Frank, B., 1968. Der Entwicklungszyklus von Psilostomum brevicolle (Creplin, 1829) (Syn.: $P$. platyurum [Mühling, 1896]) (Trematoda, Psilostomatidae). - Z. ParasitKde 31, 122-131.

Maas Geesteranus, R. A., 1942. On the formation of banks by Mytilus edulis L. - Archs néerl. Zool. 4, 283-326.

Mackenzie, K., 1968. Some parasites of 0-group plaice, Pleuronectes platessa L., under different environmental conditions. - Mar. Res. 3, 5-23.

Mahéo, R., 1970. Etude de la pose et de l'activité de sécrétion du byssus de Mytilus edulis L. - Cah. Biol. mar. 11, 475-483.

Martella, T., 1974. Some factors influencing byssus thread production in Mytilus edulis (Mollusca: Bivalvia) Linnaeus, 1758. - Wat. Air Soil Pollut. 3, 171-177.

Martin, J. M., Piltz, F. M. \& Reish, D. J., 1975. Studies on the Mytilus edulis community in Alamitos Bay, California. V. The effects of heavy metals on byssal thread production. - Veliger 18 , 183-188.

Price, H. A., 1980. Seasonal variation in the strength of byssal attachment of the common mussel Mytilus edulis L. - J, mar. biol. Ass. U. K. 60, 1035-1037.

Rees, W. J., 1936. The effect of parasitism by larval trematodes on the tissues of Littorina littorea (Linné). - Proc. zool. Soc. Lond. 1936 (1), 357-368.

Reish, D. J. \& Ayers, J. L, 1968. Studies on the Mytilus edulis community in Alamitos Bay, California. III. The effects of reduced dissolved oxygen and chlorinity concentrations on survival and byssus thread formation. - Veliger $10,384-388$.

Robson, E. M. \& Williams, I. C., 1970. Relationships of some species of Digenea with the marine 
prosobranch Littorina littorea (L.). I. The occurrence of larval Digenea in L. littorea on the North Yorkshire coast. - J. Helminth. 44, 153-168.

Robson, E. M. \& Williams, I. C., 1971a. Relationships of some species of Digenea with the marine prosobranch Littorina littorea (L.). II. The effect of larval Digenea on the reproductive biology of L. littorea. - J. Helminth. 45, 145-159.

Robson, E. M. \& Williams, I. C., 1971b. Relationships of some species of Digenea with the marine prosobranch Littorina littorea (L.). III. The effect of larval Digenea on the glycogen content of the digestive gland and foot of $L$. littorea. $-J$. Helminth. 45, 381-401.

Sindermann, C. J. \& Rosenfield, A., 1954. Diseases of fishes of the western North Atlantic. III. Mortalities of sea herring (Clupea harengus) caused by larval trematode invasion. - Res. Bull. Maine Dep. Sea Shore Fish. 21, 1-16.

Watts, S. D. M., 1971. Effects of larval Digenea on the free amino acid pool of Littorina littorea (L.). Parasitology 62, 361-366.

Werding, B., 1969. Morphologie, Entwicklung und Okologie digener Trematoden-Larven der Strandschnecke Littorina littorea. - Mar. Biol. 3, 306-333.

Winkle, W. van, 1970. Effect of environmental factors on byssal thread formation. - Mar. Biol. 7, 143-148.

Wohlenberg, E., 1937. Die Wattenmeer-Lebensgemeinschaften im Königshafen von Sylt. - Helgoländer wiss. Meeresunters. 1, 1-92. 